\title{
Korelasi Hasil Belajar Fisika Dasar dan Tafsir Terhadap Kemamapuan Integrasi Bagi Mahasiswa Jurusan Pendidikan Fisika UIN Walisongo Semester VII Tahun 2014/2015
}

\author{
Hamdan Hadi Kusuma \\ Jurusan Pendidikan Fisika, FITK UIN Walisongo Semarang
}

\begin{abstract}
Abstrak
Fisika adalah cabang ilmu pengetahuan alam (sains) yang mempelajari tentang fenomena alam secara ilmiah. Fenomena alam yang ada dan terjadi di bumi dan di langit adalah kajian sains dan sekaligus objek tafakkur kepada Allah. Pemahaman pengetahuan agama Islam (Al-Qur'an dan as sunnah) menjadi dasar untuk mempelajari fisika. Penelitian ini bertujuan untuk mengetahui hubungan hasil belajar mata kuliah fisika dasar dan pengetahuan agama Islam (Tafsir) terhadap kemampuan mengintegrasikan bagi mahasiswa Jurusan Pendidikan Fisika FITK UIN Walisongo. Hasil penelitian menunjukkan bahwa hubungan kemampuan mengintegrasikan pengetahuan agama Islam dengan konsep dasar fisika masih rendah ditunjukkan dengan nilai $r_{\mathrm{yx} 1 \times 2}=0.124$ dan $r_{\mathrm{x} 2 \times 1}=0,137$. Kondisi ini dikarena kurikulum yang ada di Jurusan Pendidikan Fisika belum menunjukkan integrasi yang jelas, yaitu muatan kurikulum yang ada belum terintegrasi walaupun sudah ada pengembangan paradigm kestuan ilmu. Integrasi nilai-nilai Islam dapat ditanamkan kepada mahasiswa melalui ranah materi, metode pembelajaran, sikap pendidik, dan lingkungan.
\end{abstract}

Kata Kunci: Integrasi; konsep fisika; Pengetahuan Agama Islam

\section{PENDAHULUAN}

Perubahan sosial-budaya adalah salah satu akibat kemajuan perkembangan teknologi yang pesat. Globalisasi ekonami yang disertai gejolak social budaya yang sulit dikendalikan akan mampu merubah pola kekuasaan dunia. Perkembangan kemajuan teknologi yang pesat dan adanya eksplorasi alam secara besar-besaran terjadi diman-mana, sehingga menimbulkan kerusakan alam. Krisis kemanusian termasuk krisis moral semakin hari semakin bertambah termasuk juga di Indonesia. Peranan keberadaan Perguruan Tinggi Agama Islam (PTAI) Indonesia menjadi salah satu ujung tombak dalam membantu mengatasi krisis kemanusia tersebut. Dewasa ini, perkembangan PTAI tidak hanya mencetak sarjana ilmu agama Islam saja tetapi juga mencetak sarjana dalam bidang ilmu umum, oleh karena itu PTAI harus melakukan suatu perubahan dengan melakukan integrasi yang tepat antar tradisi keilmuan, baik ilmu-ilmu agama, sosial, humaniora, maupun sains agar dapat mencetak generasi-generasi ilmuwan yang berakhlakul karimah (Sholihan, dkk, 2013). Ilmu-ilmu yang dikembangkan Barat pada dasarnya berbasis pada pemisahan antara sains dan ajaran moral (etika) apalagi agama (spiritual). Ilmu-ilmu produk Barat 
sesungguhnya mengantarkan manusia dalam bahaya kemanusiaan, yakni terancamnya kehidupan manusia itu sendiri (Berghout, 2012).

Implementasi paradigm sains dan agama pada dataran praktis terkadang terdapat hambatan psikologis dalam menjelaskan sebuah pengetahuan. Hal ini disebabkan masih ada sebagian orang memandang bahwa kedua paradigma tersebut memiliki orientasi dan cara yang berbeda (Karwadi, 2008). Sains dengan basis filsafat mengedepankan logika empirisme sehingga sesuatu yang dikatakan"benar"diukur berdasarkan akal dan mesti dapat dibuktikan secara empiris. Sebaliknya, agama yang didasarkan kepada ajaran normative (wahyu) menyatakan bahwa yang"benar" adalah sesuatu yang benar secara normative.

Sains Barat terbukti mendorong manusia untuk mengeksploitasi alam, tanpa mempertimbangkan kelestarian alam demi untuk mendapatkan keuntungan yang besar. Jika ini dibiarkan, maka sains yang mestinya membantu kehidupan justru akan membahayakan kehidupan. Untuk itu, sains harus diberi landasan spiritual agar berfungsi sebagaimana mestinya (Sholihan, dkk, 2013). Pemberian sentuhan spiritual terhadap sains dapat dikembangkan dengan mengintegrasikan ilmu. Integrasi yang dimaksud adalah memasukkan nilai-nilai substantif dari Islam ke dalam bangunan keilmuan baik pada level epistemologi, ontologi, maupun aksiologi.

Strategi yang dikembangkan oleh Universitas Islam Negeri (UIN) Walisongo dalam rangka mengintegrasikan ilmu adalah dengan mengembangkan paradigma unity of sciences (wahdat al-ulum) (Sholihan, dkk 2013). Dukungan terhadap pengembangan paradigma unity of sciences perlu diimplementasikan sampai ke level Jurusan atau Program studi yang ada di UIN Walisongo Semarang. Program perencanaan pembelajaran berbasis nilai agama Islam pada tingkat jurusan perlu direncanakan dengan baik dan tepat. Seperangkat program pembelajaran tersebut meliputi silabus, satuan acara perkuliahan. Hal ini merupakan langkah untuk mewujudkan dan mengimplementasikan visi UIN Walisongo dengan pengembangan paradigma unity of sciences.

Penerapan nilai-nilai agama Islam dalam prsoes pembelajaran dapat menimbulkan kesadaran peserta didik untuk lebih mendekatkan diri pada Sang Kholik. Ilmu merupakan bagian dari Islam dan hakekatnya bersumber dari Allah SWT. Pembelajaran sains harus menghantarkan kepada kesadaran terhadap nilai kebaikan dan keselamatan. Nilai inilah yang akan menciptakan kebaikan antar sesama manusia atau sains yang berbasis humaniora. Kebaikan yang bersumber dari Allah SWT dalam pembelajaran akan membentuk akhlak mulia.

Pada dasarnya, kurikulum yang sudah ada di Jurusan Pendidikan Fisika Fakultas Ilmu Tarbiyah (FITK) UIN Walisongo, telah memberikan muatan mata kuliah agama Islam yang cukup banyak yaitu 36 sks (kurikulum Jurusan Pendiidkan Fisika tahun 2010) dan selebihnya adalah untuk mata kuliah kependidikan dan mata kuliah fisika. Hal ini berarti bahwa kurikulum yang ada di Jurusan Pendidikan 
Fisika FITK UIN Walisongo telah membekali mahasiswa dengan ilmu-ilmu pengetahuan agama Islam dan ilmu sains yang cukup, sehingga lulusan mahasiswa Jurusan Pendidikan Fisika diharapkan mampu menjadi seorang saintis yang pandai dengan ilmu sainnya dan juga memahami agama Islam dengan baik dan benar serta mempunyai akhlak yang karimah. Bekal ilmu agama islam yang cukup bayak ini, maka mahasiswa Jurusan Pendidikan Fisika sebagai calon guru fisika mampu mengimplementasikan nilai-nilai Agama Islam baik ke dalam materi fisika maupun dalam metode pembelajaran fisika.

Inetgrasi keilmuan Islam dapat diimplementasikan ke dalam materi fisika dan juga dapat diimplementasikan kedalam proses serta metode pembelajaran fisika, sehingga pembelajaran fisika akan lebih menarik dan mudah difahami oleh mahasiswa (Amin, 2004). Muatan mata kuliah agama Islam yang ada pada kurikulum 2010, mahasiswa Jurusan Pendidikan Fisika diharapkan dapat memiliki kompetensi tentang pemahaman alam sebagai bagian dari ciptaan Allah SWT yang harus ditafakkuri. Pemahaman ini diharapkan dapat meningkatkan kesadaran moral dan ketaqwaan kepada Allah SWT.

Berdasarkan latar belakang yang ada tersebut, maka peneliti perlu melakukan penelitian untuk mengetahui pengaruh pemahaman ilmu agama Islam (Tafsir) dan fisika dasar terhadap kemampuan mengintegrasikan konsep fisika dengan keilmuan agama Islam bagi mahasiswa Jurusan Pendidikan Fisika angaktan $2011 ?$

\section{METODE PENELITIAN}

Penelitian ini merupakan jenis penelitian kuantitatif dengan menggunakan metode penelitian dokumentasi dan eksperimen. Bentuk eksperimen dalam penelitian ini dengan metode test. Penelitian ini dilaksanakan di Jurusan Jurusan Fisika IAIN Walisongo Semarang yang dilaksanakan pada bulan Juli 2014 sampai Oktober 2014. Populasi dalam penelitian ini adalah mahasiswa Jurusan Jurusan Fisika angakatan 2011 yang sudah lulus mata kuliah agama Islam dan matakuliah fisika dasar I dan fisika dasar II. Sampel dalam penelitian ini berjumlah 20 mahasiswa Jurusan Pendidikan angakatan 2011 yang sudah lulus mata kuliah agama Islam (ilmu tafisr) dan mata kuliah fisika dasar I.

Variabel dalam penelitian ini terdiri dari variabel bebas (independent variabel) yaitu hasil belajar mata kuliah agama Islam (variabel $\mathrm{X}_{1}$ ) dan hasil belajar fisika dasar I (variable $\mathrm{X}_{2}$ ). Variabel terikat (dependent variabel) dalam penelitian ini adalah prestasi kemampuan mengintegrasikan konsep fisika dan pengetahuan agama Islam (variabel Y). Metode yang digunkan dalam penelitian ini adalah menggunakan metode dokumentasi yaitu untuk mendapatkan nilai fisika dasar I dan nilai mata kuliah tafsir mahasiswa Jurusan Pendiidkan Fisika angkatan 2011. Metode tes digunakan untuk mengetahui hasil pengetahuan kemampuan mengintegrasikan antara konsep fisika terhadap pengetahuan agama Islam. Data penelitian di analisis dengan menggunakan analisis regresi ganda (Suharsimi. 2005) yaitu dengan mencari pengaruh anatar varaibel hasil belajara mata kuliah fisika dasar I dan mata kuliah tafsir 
terhadap kemampuan mengintegrasikan konsep fisika dasar dengan pemahaman agam Islam. Analisis regresi ganda ini dihitung dengan menggunakan berbantuan software dari W-Stats.

\section{HASIL DAN PEMBAHASAN}

Data hasil belajar mata kuliah agama Islam (tafsir) dan mata kuliah fisika dasar I didapatkan dari data dokumentasi nilai mahasiswa Jurusan Pendidikan Fisika, sedangkan data nilai kemampuan pengetahuan mengintergasikan konsep-konsep dasar fisika dengan pengetahuan agama Islam diperoleh melalui tes. Instrumen tes yang digunakan berupa soal isian yang mencakup materi fiska dasar yaitu materi besaran dan satuan, pengukuran, konsep zat, pemuaian dan kalor (Instrumen tes terlampir). Hasil data yang diperoleh dari penelitian ini ditunjukkan pada Tabel 1.

Tabel 1. Data hasil belajar fisika dasar, tafsir dan hasil tes kemampuan integrasi

\begin{tabular}{|c|c|c|c|c|}
\hline \multirow{2}{*}{ No. } & \multirow{2}{*}{ Respondent } & \multicolumn{3}{|c|}{ NILAI } \\
\hline & & Fisika Dasar I & Tafsir & Tes Integrasi \\
\hline 1 & 001 & 75 & 79 & 83 \\
\hline 2 & 003 & 68 & 77 & 79 \\
\hline 3 & 004 & 73 & 75 & 74 \\
\hline 4 & 005 & 80 & 76 & 99 \\
\hline 5 & 006 & 73 & 80 & 82 \\
\hline 6 & 007 & 67 & 78 & 38 \\
\hline 7 & 010 & 66 & 72 & 89 \\
\hline 8 & 012 & 73 & 79 & 77 \\
\hline 9 & 014 & 68 & 79 & 100 \\
\hline 10 & 015 & 72 & 80 & 97 \\
\hline 11 & 018 & 67 & 76 & 76 \\
\hline 12 & 019 & 71 & 73 & 90 \\
\hline 13 & 025 & 78 & 73 & 61 \\
\hline 14 & 026 & 75 & 75 & 100 \\
\hline 15 & 027 & 78 & 71 & 59 \\
\hline 16 & 029 & 71 & 78 & 75 \\
\hline 17 & 030 & 72 & 78 & 66 \\
\hline 18 & 032 & 75 & 76 & 100 \\
\hline 19 & 033 & 70 & 71 & 73 \\
\hline 20 & 035 & 75 & 79 & 85 \\
\hline
\end{tabular}

Data pada Tabel 1 kemudian diaanlisis dengan menggunakan uji regresi ganda yang bertujuan untuk mengetahui seberapa besar pengaruh dari kemapuan pemahaman konsep fisika dasar $\left(\mathrm{X}_{1}\right)$ terhadap kemapuan mengintegrasi (Y), kemapuan pemahaman tafsir $\left(\mathrm{X}_{2}\right)$ terhadap kemampuan mengintegrasi $(\mathrm{Y})$ dan kemampuan pemahaman konsep fisika dasar $\left(\mathrm{X}_{1}\right)$ dan kemapuan pemahaman tafsir $\left(\mathrm{X}_{2}\right)$ terhadap 
kemampuan mengintegrasi (Y). Hasil uji regresi ganda seperti terlihat pada Tabel 2 . Hasil analisis Varian pengetahuan konsep dasar fisika dan pengetahuan agama Islam terhadap kemampuan mengintegrasikan ditunjukkan pada Tabel 3, sedangkan koefisen korelasi antar variable $\mathrm{X}_{1}$ tehadap $\mathrm{Y}, \mathrm{X}_{2}$ terhadap $\mathrm{Y}$ dan $\mathrm{X}_{1}$ terhadap $\mathrm{X}_{2}$ ditunjukkan pada Tabel 4 .

Tabel 2 Hasil analisis uji regresi ganda antara hasil belajar fisika dasar dan tafsir terhadap kemampuan mengintegrasikan

\begin{tabular}{|c|c|c|c|c|c|c|c|}
\hline Variabel & $\begin{array}{l}\text { Jumlah } \\
\text { Sampel }\end{array}$ & $\begin{array}{c}\text { Nilai } \\
\text { Tertinggi }\end{array}$ & $\begin{array}{c}\text { Nilai } \\
\text { terendah }\end{array}$ & rerata & Varian & $\begin{array}{c}\text { Simpangan } \\
\text { Baku }\end{array}$ & $\begin{array}{l}\text { Galat } \\
\text { Baku }\end{array}$ \\
\hline $\mathrm{Y}$ & 20 & 91 & 25 & 55.55 & 212.78 & 14.68 & 3.26 \\
\hline $\mathrm{X}_{1}$ & 20 & 80 & 66 & 72.35 & 15.61 & 3.95 & 0.88 \\
\hline $\mathrm{X}_{2}$ & 20 & 80 & 71 & 76.25 & 8.72 & 2.95 & 0.66 \\
\hline \multicolumn{8}{|c|}{ Koefisien Regresi } \\
\hline Model & \multicolumn{2}{|c|}{$\mathrm{b}$} & \multicolumn{2}{|c|}{$\beta$} & \multicolumn{2}{|r|}{$\mathrm{t}$} & $\begin{array}{c}\mathrm{t} \text { kritis } \\
5 \%\end{array}$ \\
\hline Kons.(a) & \multicolumn{4}{|c|}{-29.16} & & & \\
\hline $\mathrm{X}_{1}$ & \multirow{2}{*}{\multicolumn{2}{|c|}{$\begin{array}{l}0.457 \\
0.677\end{array}$}} & \multirow{2}{*}{\multicolumn{2}{|c|}{$\begin{array}{l}0.124 \\
0.137\end{array}$}} & \multirow{2}{*}{\multicolumn{2}{|c|}{$\begin{array}{l}0.516 \\
0.572\end{array}$}} & \multirow{2}{*}{0.211} \\
\hline $\mathrm{X}_{2}$ & & & & & & & \\
\hline
\end{tabular}

Keterangan:

$\mathrm{Y}=$ Kemapuan integrasi konsep fisika dengan pengetahuan agama Islam

$\mathrm{X}_{1}=$ Hasil belajar Fisika Dasar I

$\mathrm{X}_{2}=$ Hasil belajar Tafsir

Tabel 3 Hasil analisis Varian pengetahuan konsep dasar fisika dan tafsir terhadap kemampuan mengintegrasikan

\begin{tabular}{|l|l|c|c|c|c|}
\hline \multicolumn{1}{|c|}{ Sumber } & \multicolumn{1}{|c|}{$\begin{array}{c}\text { Jumlah } \\
\text { Kuadrat (JK) }\end{array}$} & $\begin{array}{c}\text { Derajt } \\
\text { Kebebasan } \\
(\mathrm{DK})\end{array}$ & $\begin{array}{c}\text { Rerata } \\
\text { Kuadrat } \\
(\mathrm{RK})\end{array}$ & F & $\begin{array}{c}\text { Taraf Signifikan } \\
(\rho)\end{array}$ \\
\hline Regresi & 125.764 & 2 & 62.882 & \multirow{2}{*}{0.273} & 3.592 \\
\hline Residu & 3913.186 & 17 & 230.423 & & \\
\hline Total & 4042.950 & 19 & & & \\
\hline
\end{tabular}

Tabel 4 Koefisen korelasi antar variabel $\mathrm{X}_{1}$ tehadap $\mathrm{Y}, \mathrm{X}_{2}$ terhadap $\mathrm{Y}$ dan $\mathrm{X}_{1}$ dan $\mathrm{X}_{2}$ terhadap $\mathrm{Y}$

\begin{tabular}{|l|c|}
\hline \multicolumn{1}{|c|}{ Antar Variabel } & $\mathrm{r}$ \\
\hline Hasil belajar fisika dasar I terhadap Kemampuan Integrasi & 0.112 \\
\hline Hasil belajar tafsir terhadap Kemampuan Integrasi & 0.126 \\
\hline Hasil belajar fisika dasar I dan tafsir & -0.089 \\
\hline
\end{tabular}

Tabel 5 Koefisen korelasi parsial antar variabel $\mathrm{X}_{1}$ dan $\mathrm{X}_{2}$ terhadap $\mathrm{Y}$, dan Koefisen korelasi parsial antar variabel $\mathrm{X}_{1}$ dan $\mathrm{X}_{2}$ terhadap $\mathrm{Y}$

\begin{tabular}{|c|c|}
\hline Antar Variabel & $\mathrm{r}$ \\
\hline Hasil belajar fisika dasar I terhadap Kemampuan Integrasi setelah & $\mathrm{R}_{\mathrm{y} .1 .2}=0.124$ \\
\hline
\end{tabular}


pengaruh tafsir dihilangkan

Hasil belajar tafsir terhadap Kemampuan Integrasi setelah $\mathrm{R}_{\mathrm{y} .1 .2}=0.137$

pengaruh fisika dasar I dihilangkan

Data hasil uji regresi ganda linier untuk dua predictor (hasil belajar fisika dasar dan tafsir) seperti terlihat pada Tabel 1 dapat dibuat persamaa sebagai berikut:

$$
Y=.-29.16+0.457 X_{1}+0.677 X_{2}
$$

Persamaan regersi yang dihasilkan dari analisis uji regresi didapatkan seperti pada persamaan 1. Nilai konstanta a pada persamaan regresi berga negatif. Nilai negatif ini tidak menjadi masalah sepanjang $\mathrm{X}_{1}$ dan $\mathrm{X}_{2}$ tidak mungkin sama dengan 0 karena tidak mungkin dilakukan. Hal yang perlu dipertimbangkan justru mencari nilai $X_{1}$ dan $X_{2}$ terendah (Sunaryanto, 1994).

Hasil analisis varian untuk mengetahui pemahaman pengetahuan konsep dasar fisika dan tafsir terhadap kemampuan mengintegrasikan seperti ditunjukkan pada Tabel 3. Hasil uji varian didapatkan nila $F_{\text {hitung }}$ sebesar 0.273 , sedangkan $F_{\text {tabel }}=3.592$. Hipotesis yang diajukan untuk uji varian adalah :

$\mathrm{H}_{0}=$ tidak terdapat perbedaan antara kemampuan konsep dasar fisika dan pengetahuan tafsir terhadap kemampuan mengintegrasikan.

$\mathrm{Ha}=$ ada perbedaan antara kemampuan konsep dasar fisika dan pengetahuan tafsir terhadap kemampuan mengintegrasikan.

Hasil uji analisi varian didapatkan bahwa $\mathrm{F}_{\text {hitung }}<\mathrm{F}$ table, sehingga Ho diterima dan Ha ditolak.. Jadi tidak ada perbedaan antara kemampuan pengtahuan konsep dasar fisika dan tafsir terhadap kemampuan mengintergrasi konsep fisika dan pengetahuan agama. Hal ini menunjukkan bahwa mahasiswa Jurusan Pendidikan Fisika angkatan 2011 memiliki kemampuan yang sama dalam pemahaman konsep dasar fisika dan pemahaman tafsir.

Hasil uji hubungan antar variable seperti ditunjukkan pada Tabel 4 dan Tabel 5, didapatkan bahawa hubungan hasil belajar fisika dasar I terhadap kemampuan integrasi mahasiswa jurusan pendidikan fisika angkatan 2011 dengan nial $\mathrm{r}$ sebesar $=0.112$, sedangkan hubungan hasil belajar tafsir terhadap kemampuan integrasi dengan nilai $r$ sebesar $=0.126$. Hasil uji hubungan antara variable ini menunjukkan bahwa pada masing-masing pembelajaran baik pada pembelajaran konsep fisika dasar I dan pembelajaran tafsir tidak di integrasikan diantara kedua disiplin ilmu tersebut.Hal ini ditunjukkan dari nilai $r$ hirung pada masing-masing mata kuliah terhadap kemmapuan intehgrasi yang sangat rendah sekali. Jadi prose pembelajaran yang dilaksanakan di Jurusan pendidikan Fisika selama ini, hanya dilakukan secara tersendiri-sendiri tanpa mengkaitkan atau mengintegrasikan materi kuliah dengan keilmuan yang lain terutama dalam pengetahuan agama Islama. Nilai hubungan hasil belajar fisika dasar I terhadap hasil 
belajar tafsir sebesar $=-0.089$. Hal ini menunjukkan bahawa keberadaan pemahaman konsep dasar fisika tidak dijelaskan dalam kaitannya dengan menghubungkan ilmu-ilmu keagamaan.

Nilai rata-rata kemampuan mengintegrasikan konsep dasar fisika dengan pengetahauan tafsir mahasiswa pendidikan Fisika FITK UIN Walisongo Semarang adalah mencapai nilai 55.55, yaitu masih jauh di bawah nilai kelulusan yang harus dicapai oleh mahasiswa yaitu mencapai nilai 60. Kondisi ini disebabkan oleh banyak faktor diantaranya faktor kemampuan mahasiswa baik kemampuan dalam memahami pengetahuan agama Islam maupun kemampuan memahami konsep dasar fisika itu sendiri, faktor kurikulum IAIN Walisongo terutama kurikulum di Jurusan Pendidikan Fisika yang belum terintegrasi baik pada mata kuliah agama Islam maupun pada mata kuliah fisika terutama pada mata kuliah fisika dasar.

Dosen-dosen pengajar mata kuliah agama Islam seperti fiqih, ulumul Qur'an, ulumul hadits, bahasa arab, tafsir, dan dirosah agama islam, masing-masing masih belum memberikan sentuhan interkoneksi atau mengkaitkan dengan peristiwa-peristiwa yang ada di alam (peristiwa sains). Demikian juga dengan dosen-dosen yang mengampau mata kuliah fisika belum memberikan sentuhan yang sama dengan menginterkoneksikan atau mengkaitkan konsep dasar materi fisika dengan dalil-dalil naqli atau pengetahuan agama Islam. Kondisi inilah yang mempengaruhi adanya kemampuan pengetahuan mahasiswa Jurusan Pendidian Fisika angkatan tahun 2011 dalam mengintegrasikan konsep-konsep fisika dasar dengan ilmu pengetahuan agama Islam belum bisa tercapai.

Pada Tabel 1 terlihat bahwa nilai mata kuliah tafsir yang dicapai oleh mahasiswa Jurusan pendidikan Fisika angkatan 2011 adalah rata-rata mendapatkan nilai 76.25, sedangkan nilai fisika dasar adalah mendapatkan rata-rata 72,35. Ketercapaian nilai mata kuliah agama Islam dan nilai mata kuliah fisika dasar ini tidak dapat dijadikan acuan bahwa mahasiswa tersebut dapat mengintegrasikan pengetahuan agama Islam dengan konsep dasar fisika melalui pemahaman ilmu agama. Hal ini terbukti bahwa hasil nilai tes kemampuan pengetahuan mengintegrasikan konsep agama Islam dengan konsep dasar fisika melalui dalil-dalil naqli mendapat nilai dibawah 60 (mendapatkan nilai rata-rata 55.55). Kenyataan ini harus disadari oleh semua pihak baik dosen-dosen agama Islam maupun dosen-dosen Jurusan Jurusan Fisika.

Kadar optimalisasi pembelajaran fisika berbasis nilai Agama Islam bergantung kepada kemampuan tenaga pendididk dalam menguasai komsep fisika, konsep Agama Islam dan kemampuan pedagogic secara integrasi sehingga terjadi pengaruh induktif dan berdampak pada peserta didik dalam menintegrasikan nilai-niali Agama Islam pada kehidupan sehari-hari.

Lubis dan Widayana (2001) mengungkapkan bahwa nilai religius dapat dikaji melalui pembelajaran fisika. Pada fisika sering digunakan simbol yang mempunyai nilai atau harga tertentu. Sebagai contoh, suatu kawat baja memiliki perilaku tertentu apabila ditarik yang dinyatakan dengan sebutan elastisitas. Kawat lain dari bahan yang lain akan mempunyai simbol elastisitas yang sama namun harganya berlainan. Hal ini menunjukkan bahwa segala sesuatu telah ditetapkan Allah dengan ukuran-ukuran 
tertentu. Nilai-nilai religius dalam pola perkembangan Islam di dunia, seolah-olah terpisah dari sains. Studi secara mendalam tentang Al-Qur'an dan hadits menyatakan bahwa hal ini seharusnya tidak demikian. Sikap Islam tentang sains.

Implementasi paradigma unity of sciences ini juga harus diterapkan oleh dosen-dosen dalam proses pembelajaran, baik dosen dari ilmu Agama Islam maupun dosen dari ilmu fisika sendiri. Selama proses pembelajaran berlangsung, seorang dosen ilmu agama Islam harus mempunyai kemampuan untuk memberikan contoh konsep-konsep agama yang diintegrasikan dengan konsep-konsep ilmu alam (sains). Demikian juga dengan dosen fisika harus juga mampu mengintegrasikan konsep-konsep fisika dengan konsep-konsep agama Islam terutama dengan mengaitkan dalil-dalil naqli yang ada. Pengintegrasian ini dapat dilakukan dengan berbagai cara diantaranya dengan mengintegrasikan pada materi, metode pembelajaran dan sikap dari seorang dosen serta lingkungan kampus.

Pembelajaran fisika menghendaki adanya hubungan konseptual antara representasi makroskopis, mikroskopis, dan simbolis. Kurikulum mata kuliah fisika harus membimbing mahasiswa untuk menggunakan berbagai macam representasi fisika secara visual dan verbal. Suatu konsep dalam representasi fisika, dimaknai melalui sebuah proses sentral dengan menghubungkan konsep-konsep tersebut dengan konsep-konsep lainnya yang sama atau relevan. Dalam hal ini, representasi fisika bisa menjadi lebih dipahami mahasiswa ketika representasi fisika tersebut dihubungkan dengan teks-teks lain yang relevan yang telah diketahui siswa, termasuk representasi yang dipelajari sebelumnya, nilai-nilai Islam agama, serta pengalaman yang mereka miliki. Pertautan yang dibangun mahasiswa di antara representasi fisika, pengalaman hidup sehari-hari, dan kejadian-kejadian di dalam kelas dapat dipandang sebagai hubungan intertekstualitas (Wu, 2002:4).

Ilmu Fisika mengandung banyak sekali nilai-nilai kehidupan. Nilai moral yang dapat dikembangkan dalam hal ini menyangkut nilai kejujuran, rasa ingin tahu, serta keterbukaan. Proses sains dalam hal ini merupakan proses mempelajari serta mengambil makna pada kehidupan dan dunia di sekeliling kita. Banyaknya nilai penting kehidupan yang dapat dipelajari dari fisika. Hal ini memberikan konsekuensi kepada para pendidik untuk dapat mengembangkan sains sebagai salah satu media dalam membentuk pribadi siswa. Dalam hal ini, siswa dapat diajak menelaah serta mempelajari nilai-nilai dalam fisika yang berguna dalam kehidupan bermasyarakat (Sumaji et al., 1998 :116-117). 


\section{KESIMPULAN}

Ilmu fisika mengandung banyak sekali nilai-nilai kehidupan. Nilai moral yang dapat dikembangkan dalam hal ini menyangkut nilai kejujuran, rasa ingin tahu, serta keterbukaan. Proses fisika dalam hal ini merupakan proses mempelajari serta mengambil makna pada kehidupan dan dunia di sekeliling kita. Banyaknya nilai penting kehidupan yang dapat dipelajari dari fisika. Hal ini memberikan konsekuensi kepada para pendidik untuk dapat mengembangkan fisika sebagai salah satu media dalam membentuk pribadi mahasiswa yang memiliki kepribadian berakhalkul karimah. Kemampuan mengintegrasikan antara semua ilmu harus didukung dari berbagai pihak yang terkait. Pengintegrasian dapat dialkukan dari bebagai domain yaitu domanin materi yang dipelajari, metode pembelajaran, prilaku pendidik, dan lingkungan yang mendukug. 


\section{DAFTAR PUSTAKA}

Abdullah, Amin dkk, Integrasi Sains - Islam Mempertemukan Epistemologi Islam dan Sains, (Yogyakarta: Pilar Religia, 2004).

Arikunto, Suharsimi. 2005. Dasar-dasar Evaluasi Pendidikan. Jakarta: Bumi Aksara . 2006. Prosedur Penelitian Suatu Pendekatan Praktik. Jakarta: Rineke Cipta.

Bagir, Zainal Abidin. "Bagaimana 'Mengintegrasikan’ Ilmu dan Agama” dalam Zainal Abidin Bagir, et.al., Integrasi Ilmu dan Agama: Interpretasi dan Aksi (Bandung: Penerbit Mizan, 2005), 20.

Berghout, 2012. Abdel Aziz, "Toward Islamic Framework for Worldview Studies: Preliminary Theorization", Makalah disampaikan dalam Workshop Penyusunan Blueprint Pengembangan Akademik Proyek Pengembangan Akademik (IAIN Sumatera Utara, IAIN Raden Fatah Palembang, IAIN Walisongo Semarang, dan IAIN Mataram), Hotel Mikie Holiday, Berastagi.

Kaawardi, 2008. Integrasi Paradigma Sains dan Agama dalam Pembelajaran Aqidah (Ketuhanan): Telaah Perspektif kurikulum Integratif. Journal Penelitian Agama, Vol XVII (no.3).

Lubis dan Widayana .2003. Suplemen Fisika Untuk Peningkatan Imtaq Siswa SMA. Jakarta: Bagian Proyek Peningkatan Wawasan Keagamaan Guru, Direktorat Pendidikan Dasar dan Menengah, Departemen Pendidikan Nasional.

Rietvield, Piet dan Lasmono Tri Sunaryanto. 1994. 87 Masalah Pokok dalam Regresi Berganda. Yogyakarta: Andi Offset.

Sholihan, Muhyar Fanani, Hamdan Hadi Kusuma, M. Jandra Bin Mohd Janan, Azmi Shah bin Suratman dan Ramli bin Awang, 2013. Nilai-nilai Keislaman dalam Pendidikan Sains dan Teknologi di Perguruan Tinggi Malaysia. Penelitian koloboratif IAIN Walisongo dengan Universiti Teknologi Malayasia.

Sumaji,dkk. .1998. Pendidikan Sains yang Humanistis. Yogyakarta: Kanisius.

Wu, Hsin-Kai. 2002. "Linking The Microskopik View of Chemistry to Real Life Experience: intertekstuality in a High School Science Class Room”. Journal Chemical Education. TaipeiTaiwan: National Taiwan Normal University, hlm1-48.Taipei- Taiwan: National Taiwan Normal University, hlm1-48. 